\title{
0 desafio das agências reguladoras ao redor do mundo no uso do glifosato
}

\section{The challenge for regulatory agencies around the world in the use of glyphosate}

\author{
Diego Zapelini do Nascimento ${ }^{a}$ \\ (iD) https://orcid.org/0000-0002-7323-185X \\ E-mail: diegozapnascœgmail.com \\ Gabriela Moreno Marques ${ }^{a}$ \\ (iD) https://orcid.org/0000-0001-9296-7574 \\ E-mail: gabii_moreno®hotmail.com \\ Daisson José Trevisol ${ }^{a}$ \\ (D) https://orcid.org/0000-0002-7053-9082 \\ E-mail: daissontðuol.com.br \\ anniversidade do Sul de Santa Catarina. Tubarão, SC, Brasil.
}

\section{Correspondência}

Diego Zapelini do Nascimento

Av. José Acácio Moreira, 787, Dehon. Tubarão, SC, Brasil. CEP 88704-900.
O estudo "Processo sócio-sanitário-ambiental da poluição por agrotóxicos na bacia dos rios Juruena, Tapajós e Amazonas em Mato Grosso, Brasil”, de Oliveira et al. (2018), nos incentiva a contribuir para o debate sobre a tomada de decisões de todas as agências reguladoras ao redor do mundo na utilização de herbicidas à base de glifosato. Na Europa, assim como no Brasil, o uso do glifosato está em discussão, e apesar das evidências dos riscos encontrados, a Comissão Europeia decidiu continuar com o uso. Oliveira et al. (2018) enfatizam o risco carcinogênico do uso do glifosato, e esta associação está de acordo com o parecer emitido pela Agência Internacional de Pesquisa sobre o Câncer da Organização Mundial da Saúde (OMS), que aponta o glifosato como provável agente carcinogênico (Van Straalen; Legler, 2018). 0 risco de desenvolver doença celíaca e intolerância ao glúten, apontado pelos autores, pode ser explicado pelo fato de que este herbicida possui a capacidade de inibir as enzimas do citocromo P450. Além disso, as deficiências em ferro, cobalto, cobre, molibdênio e outros metais raros associadas à doença celíaca podem ser atribuídas à forte habilidade do glifosato de quelar esses elementos (Samsel; Seneff, 2013). Nos Estados Unidos, o uso do glifosato também é permitido, e a doença celíaca tornou-se uma epidemia crescente na potência mundial e cada vez mais em todo o mundo (Green; Cellier, 2007). Os pacientes com doença celíaca têm maior risco de desenvolver linfoma não-Hodgkin (Samsel; Seneff, 2013), outro agravo crônico apontado por Oliveira et al. (2018). Outra doença associada ao uso do glifosato, prevalente nas sociedades ocidentais, que não foi relatada pelos autores, mas está presente na literatura científica, é o Transtorno do Déficit de Atenção e Hiperatividade (TDHA) (Fluegge, 2017). Sendo um derivado da glicina, o glifosato pode 
substituir o aminoácido nativo em proteínas, sendo um fator para o desenvolvimento de diversas outras doenças, incluindo hipotireoidismo, doença de Parkinson, glaucoma, osteoporose, esclerose lateral amiotrófica e lúpus (Mesnage; Antoniou, 2017; Samsel; Seneff, 2016). No Brasil, país com maior consumo de agrotóxicos, devido às culturas de exportação, como a soja, o algodão, a cana-deaçúcar, o tabaco e algumas frutas, produzidas no modelo do agronegócio, apesar da proibição do glifosato ser uma recomendação do Ministério Público Federal, a Agência Nacional de Vigilância Sanitária (Anvisa) decidiu continuar com o uso e realizar outras análises toxicológicas (Jacobi; Giatti; Toledo, 2016). Desta forma, existe a necessidade do apelo aos governos e agências reguladoras para que reconsiderem políticas relativas à segurança da utilização de glifosato nos alimentos e seu real impacto nos ecossistemas (FahrenkampUppenbrink, 2018).

\section{Referências}

FAHRENKAMP-UPPENBRINK, J. Glyphosate: menace or savior? Science, Washington, DC, v. 36o, n. 6392, p. 978-978, 2018.

FLUEGGE, K. Autism in 2016: additional discovery. Jornal de Pediatria, Porto Alegre, v. 93, n. 3, p. 308-309, 2017.
GREEN, P. H. R.; CELLIER, C. Celiac disease. New England Journal of Medicine, Waltham, v. 357, n. 17, p. 1731-1743, 2007.

JACOBI, P. R.; GIATTI, L.; TOLEDO, R. F. A reflexividade em oposição à massificação da produção agrícola. Ambiente \& Sociedade, Campinas, v. 19, n. 3, p. 1-6, 2016.

MESNAGE, R.; ANTONIOU, M. N. Facts and fallacies in the debate on glyphosate toxicity. Frontiers in Public Health, Lausanne,

v. 5, p. 1-7, 2017.

OLIVEIRA, L. K. et al. Processo sócio-sanitárioambiental da poluição por agrotóxicos na bacia dos rios Juruena, Tapajós e Amazonas em Mato Grosso, Brasil. Saúde e Sociedade, São Paulo, v. 27, n. 2, p. 573-587, 2018.

SAMSEL, A.; SENEFF, S. Glyphosate, pathways to modern diseases II: celiac sprue and gluten intolerance. Interdisciplinary Toxicology, Varsóvia, v. 6, n. 4, p. 159-84, 2013.

SAMSEL, A.; SENEFF, S. Glyphosate pathways to modern diseases V: amino acid analogue of glycine in diverse proteins. Journal of Biological Physics and Chemistry, Basileia, v. 16, n. 1, p. 9-46, 2016.

VAN STRAALEN, N. M.; LEGLER, J. Decisionmaking in a storm of discontent. Science, Washington, DC, v. 36o, n. 6392, p. 958-96o, 2018. 